\title{
UDC 004.896
}

\author{
Bogdan A. Palchevskyi \\ Doctor of Technical Sciences, Professor \\ Lutsk National Technical University, Lutsk, Ukraine \\ ORCID ID 0000-0002-4000-4992 \\ pac@tf.dtu.lutsk.ua
}

Olena A. Krestyanpol

PhD of Technical Sciences, Associate Professor

Lutsk National Technical University, Lutsk, Ukraine

ORCID ID 0000-0002-6631-0226

helenakrist61@gmail.com

Lyubov Yu. Krestyanpol

PhD of Technical Sciences, Associate Professor

Lutsk National Technical University, Lutsk, Ukraine

ORCID ID 0000-0003-3617-7900

Krist_88@i.ua

\section{THE USE OF ANYLOGIC SYSTEM FOR MODELLING A FLEXIBLE AUTOMATED PACKING SYSTEM IN TRAINING ENGINEERING STUDENTS}

\begin{abstract}
The authors have considered possibilities of organizing the training of students majoring in engineering specialty "131. Applied Mechanics" in the course "CAD of packaging production" using the specialized software of the AnyLogic Company.

The paper presents software products for automated calculation and modeling of the technological process of packaging. As a result of studying the software product, the students will be able to master the techniques of automated calculation and design of packaging components and implement projects using modern CAD and CAM systems.

The purpose of modeling the technological processes of packaging is to increase their productivity by determining and justifying the optimal parameters. The study of technological processes based on simulation modeling allows the students to identify interconnections, to highlight technical and economic indicators, to evaluate the impact on profitability, to determine the directions of development and ways to improve the technical and technological facilities.

The methodology for developing a flexible automated line simulation model, for example, for the production of macaroni products, is described in this work. Authors highlighted the stages of modelling a flexible automated packaging system.

The criteria that influence the technological process of bulk products packing are determined. The parameters for constructing the simulation model are selected. A formal description of the packing line has been made for a more detailed understanding of the process and the adequate construction of the model. With the help of the software of The AnyLogic Company, students create an acting part of the model, simulate processing at workshops and the work of a warehouse.

As a result, in the developed simulation model, the authors researched the load of the production elements, determined problematic structural elements and calculated the coefficient of the technological line readiness. The virtual model of the technological line allowed testing the future technological line for adequacy, process ability and reliability.

As a result of studying the discipline "CAD of packaging production" and AnyLogic software, students develop holistic understanding of the automated process and acquire the skills of modeling, analysis and optimization of the technological line.
\end{abstract}

Keywords: simulation modelling; flexible automated system; model; formalized description; coefficient of readiness; discrete-event abstraction; logical circuit. 


\section{INTRODUCTION}

The problem setting. Automation of design works gives the possibility to increase significantly labour productivity in designing, improve the quality of design documentation, reduce the machinery design period, and improve the quality and technical and economic level of machines both at the stage of their design and operation. It is safe to say that the competitiveness of newly created machines is largely determined at the stage of their design, effectiveness of which is directly related to the automation level of all stages of the multistage design process.

Statistical data obtained from machine-building enterprises shows (Table 1) that the drawing work takes more than $30 \%$ in direct hours for designing, while the creative elements of design work take only $15 \%$. The share of computing work in comparison with designing and drawing work in percentage terms is rather small. Other, so-called indirect designing works, take about one third of total designing time.

The results of the surveys clearly show that the "routine" procedures, which include detailing, take a large part of hours in the design process. Therefore, at the beginning of the designing work automation, the desire to automate these stages with the help of computer technology dominated. A significant incentive for the development of virtual design systems for complex technical objects, including technological machines, appeared about 30 years ago, when a graphical computer image became available.

The accumulated experience shows that the automation of only certain designing operations using the computer to perform drawing work and engineering calculations does not significantly change the designing period.

But at the same time, it becomes clear that the main direction here is not the automation of individual designing stages, not algorithms of engineering calculations, but the creation of integrated automated virtual design systems that cover the designing stages from the project start, when only contours of the future machine are made, which should correspond to the initial plans, to its final design. Within such approach, the quality of the design decisions is increased due to the applied optimal design methods.

Analysis of recent research and publications. Virtual simulation is a model designing tasks solution using a computer, that is, automated CAD-based design. Computer systems allow students to simulate the full design development process on computer models, create cybernetic prototypes of process machines, lines or processes and to test them virtually in a model environment. When studying "CAD of packaging production", students simulate the technological process using AnyLogic simulation environment.

Borshchev [1], comprehensively presents all three methods, or paradigms, in simulation modeling: Agent Based, System Dynamics, and Discrete Event. The work explains how to choose the right constructs of the modeling language to create a representation of a real world system that is suitable for risk-free dynamic experiments. This book is extremely useful to both simulation professionals and students learning simulation modeling.

C.M. Macali, M.J. North in article [2] provide a brief introduction to agent-based modelling and simulation, illustrate the main concepts and foundations, discuss some recent applications across a variety of disciplines, and identify methods and toolkits for developing agent models.

Gizem Gunes and Ali Fuat Guneri [3] in their work combined the main concepts of C.M. Macali and their practical implementation in AnyLogic.

Björn F. Postema, Boudewijn R. Haverkort, in "An AnyLogic simulation model for power and performance analysis of data centres" [4] present high-level models to estimate DC power consumption and performance. This demonstrates the universality of AnyLogic and the possibility of its use in solving complex engineering problems. 
Analyzing the works of O.V.Karsayev and others [5], it can be concluded that the AnyLogic simulation environment is flexible and can be used in various fields. According to I. N. Khaymovich, D.G. Skripachev, S.Yu. Kolesnikova [6], the study of AnyLogic simulation environment is compulsory for engineering students. E. V. Karmanova and others argue that the software allows you to create a model of the production process and to evaluate the impact of changes in various parameters of the system on the course of the production process [7]. The application of this software will allow students to form a clear understanding of the production process.

AnyLogic simulation environment is based on an object-oriented concept and has a number of benefits. Some of them are the existence of all modelling paradigms (high choice flexibility of the approach); the possibility of choosing between paradigms or applying an integrated approach; it has all the properties necessary for the development of simulation models [8]. AnyLogic environment is developed in a universal Java programming language, which allows it not to depend on the type of operating system $[9,10]$.

Unsolved aspects of the target. Studying and further use of the simulation means by students of engineering specialties is a necessity today. Creation and wide implementation of automated design systems into production is based on creation of a virtual computer prototype, a prototype of a future technological machine. In this case, the work on the project is accelerated; the number of errors is reduced. However, it is not always clear if the software product is suitable for simulation.

The purpose of the article is to investigate production elements load using the environment for simulation modeling and creating a computer model of the packaging line for macaroni products in the course "CAD of packaging production" for engineering students.

\section{THE RESULTS OF THE RESEARCH}

The curriculum of students in the specialty "131.Applied Mechanics" majoring in "Machines and Technology of Packaging" at Lutsk National Technical University includes the study of the course "CAD of packaging production". Besides software for creating drawings and models - AutoCad, Creo Parametrix, SolidWorks, Compas, students study AnyLogic simulation environment. Teaching "CAD of packaging production" is based on a combination of students' theoretical knowledge with their practical skills. In particular, when studying the simulation environment, students create models of technological processes at existing enterprises. Then they determine the weak points in the technological line, the joints with the highest failure rate and the optimal combination and placement of technological machines. It provides students with practical skills and knowledge that they further can implement at the enterprise.

Simulation modeling consists of two major stages: the creation of a model and the analysis of the data obtained with the help of a decision model [11].

First of all, a student must determine what tasks they have to deal with. The goal depends on what processes in the real system should be selected and displayed in the model, and which processes should be left out, which characteristics of these processes should be considered and which - not, which correlations between the changes and model parameters should be reflected in the model.

This stage can be described as the creation of a conceptual (content) model. The structuring of the model is being provided at this stage, that is, the selection of individual subsystems, the definition of elementary components of the model and their relationships at each level of the hierarchy. 
The elements of the system, their relationships, parameters and variables, as well as their relationships and the laws of their changes, must be expressed by means of the simulation environment, that is, in this environment, variables and parameters of the model must be defined, procedures for calculating changes of the variables and model characteristics in time must be constructed.

If necessary, for a better understanding of the processes occurring in the model, students develop an animation of these processes [12].

The constructed model is verified in terms of the correctness of its implementation.

The next step is to calibrate or identify the model, that is, to collect data and perform measurements of those characteristics in the real system that the student introduces into the model in the form of values of parameters and distributions of random variables.

Next it is necessary to perform a check of the correctness of the model (its validity). For this purpose, the output model is checked in several test modes, in which characteristics of the behavior of the real system are known or obvious.

The final stage of working with the model is a computer experiment, which is actually the aim of creating the model.

To study AnyLogic simulation environment in our case, students need to simulate the work of a flexible automated packaging system on the example of macaroni production. For this purpose, it is necessary to simulate production with the following stages and the duration of their operations (Table 1). Duration of each of the stages is obtained experimentally.

Table 1

\section{Duration of production stages}

\begin{tabular}{|l|c|c|}
\hline Production stage & Number & Duration, minutes \\
\hline Press and pre-drying & 1 & 5 \\
\hline Drying No.1 & 2 & 55 \\
\hline Drying No.2 & 3 & 300 \\
\hline Refrigeration unit & 4 & 5 \\
\hline Hopper & 5 & $50-80$ \\
\hline Packing machine $1 \mathrm{~kg}(0,9 \mathrm{~kg})$ & 6 & 0,077 \\
\hline Packing machine 3kg (2kg) & 7 & 0,066 \\
\hline Finished product warehouse & 8 & - \\
\hline
\end{tabular}

Having this technological equipment, it is possible to produce 7 types of products: rolls; spirals; elbow macaroni; cuts of straw; vermicelli; shells; turtles.

Due to different shape of products, and as a result of their looseness, the filling time of hoppers for different types of products is also different. The data on the filling of hoppers, obtained experimentally, are given in Table 2.

Table 2

Time of filling the hopper with finished products

\begin{tabular}{|l|c|}
\hline Type of product & $\begin{array}{c}\text { Filling time, } \\
\text { minutes }\end{array}$ \\
\hline rolls & 55 \\
\hline spirals & 50 \\
\hline elbow macaroni & 60 \\
\hline cuts of straw & 70 \\
\hline vermicelli & 80 \\
\hline shells & 60 \\
\hline turtles & 70 \\
\hline
\end{tabular}


First of all, you need to define the input parameters for the simulation model. The input parameters of the model are:

- type of product;

- speed of the conveyor;

- parameters of packing machines (weight of packed products);

- breakage of conveyors.

It should be noted that all parameters can be changed directly at the time of modelling.

\subsection{The formalized description of the model consists of the exact location of the} equipment and its functions, which later will form the simulation model.

The line works as follows: pasta is squeezed out and then goes to pre-drying, where it is pre-crushed and dried. After that, the product is delivered to the dryer by basket conveyor number 1, where it passes through the system of belt conveyors and is dried for 55 minutes. The pasta is then fed into the basket conveyor after drying number 2, where the products pass through the system of conveyors and finally is dried for 5 hours. Finished pasta after drying number 2 is fed into the refrigeration unit by a basket conveyor. After that, the product is delivered to one of the unfilled hoppers by belt conveyors. From the filled hopper, the product enters one of the vending machines depending on the customer's requests. Packers put the packaged products on pallets, which, after they are full, an electric loader transports to the warehouse of finished products [13].

This model will be done in a discrete-event abstraction. First, you need to make a layout of the key elements of the model (Figure 1).

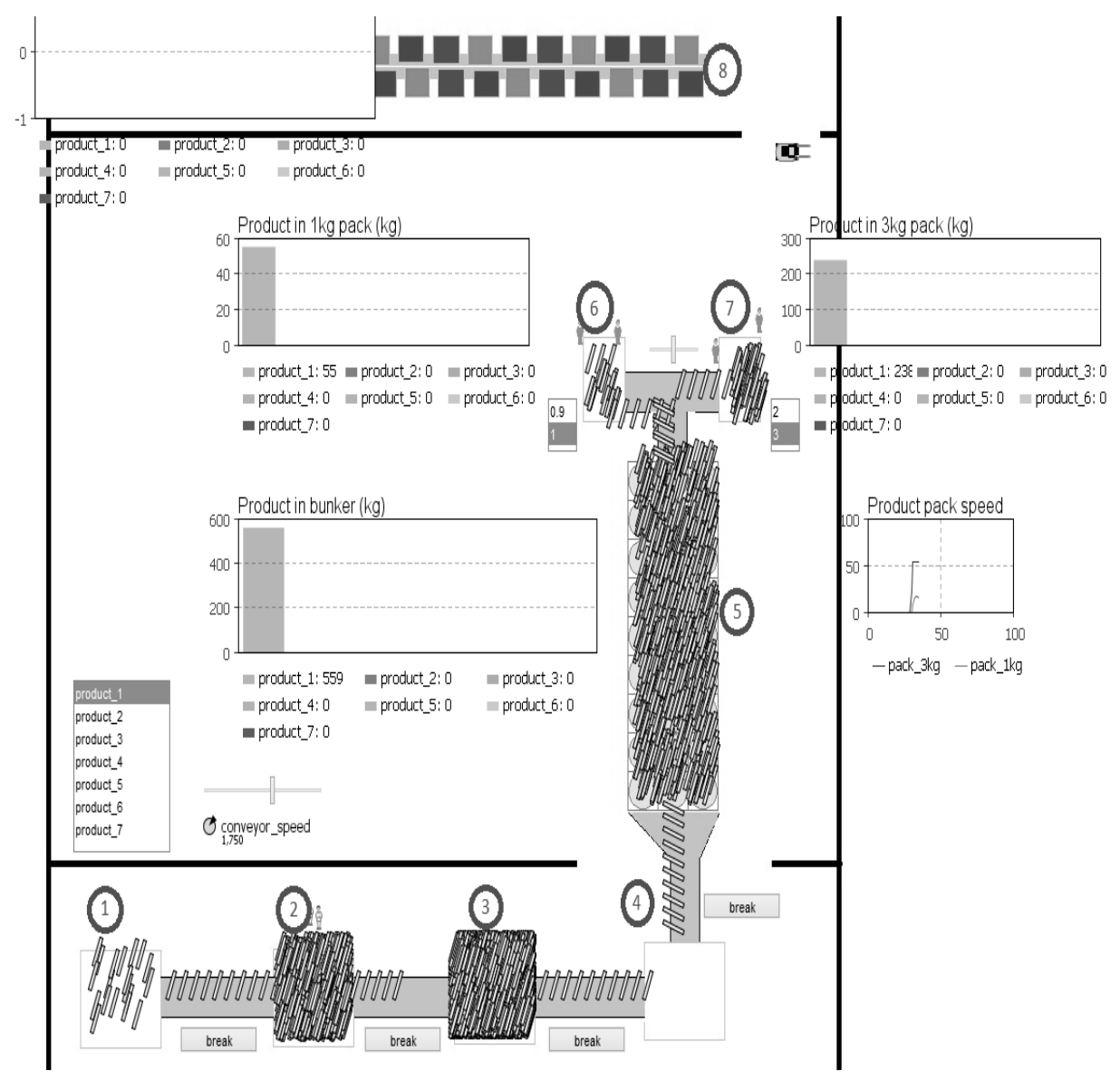

Fig.1. Key elements of the model 
Entering input data should start with view control.

Product management is possible by selecting a particular item from the list of available types. Let's look at Figure 2.

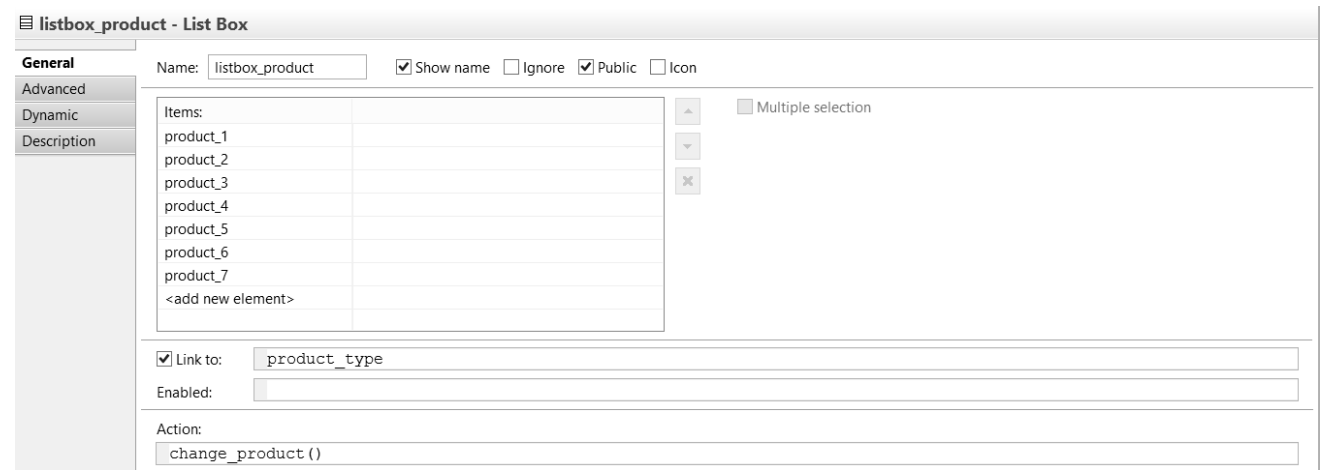

Fig.2. The box of product view configuration in AnyLogic

As you can see, list of available types is bound to the variable product_type (Figure 2), and when you select any item in the list, the function change_product is called. This is a variable of string type, which acquires the value of the name of the active item in the list. This function, depending on the value of the product_type variable, changes the value of the product_shape variable, and then calls the break_manufacture function.

Depending on the chosen type of the product, we change the two variables, product_type and product_shape.

The elements of selecting the type of packaging work in the same way.

Next, let us consider the element that simulates the breakage control on the line - this is the break element. This item is a button. It calls the break_manufacture function. Depending on the type of breakdown, the variables will change.

The last element is the conveyor speed control element. This element is a slider; it changes the value of the conveyor_speed variable. This variable is responsible for the speed of the conveyor in the logical circuit of production.

The output of the simulation results is on the charts. They all work in the same way, let us look at one of them, namely Product_in_bunker_kg, which shows the number of products in hoppers ready for packaging (Figure 3).

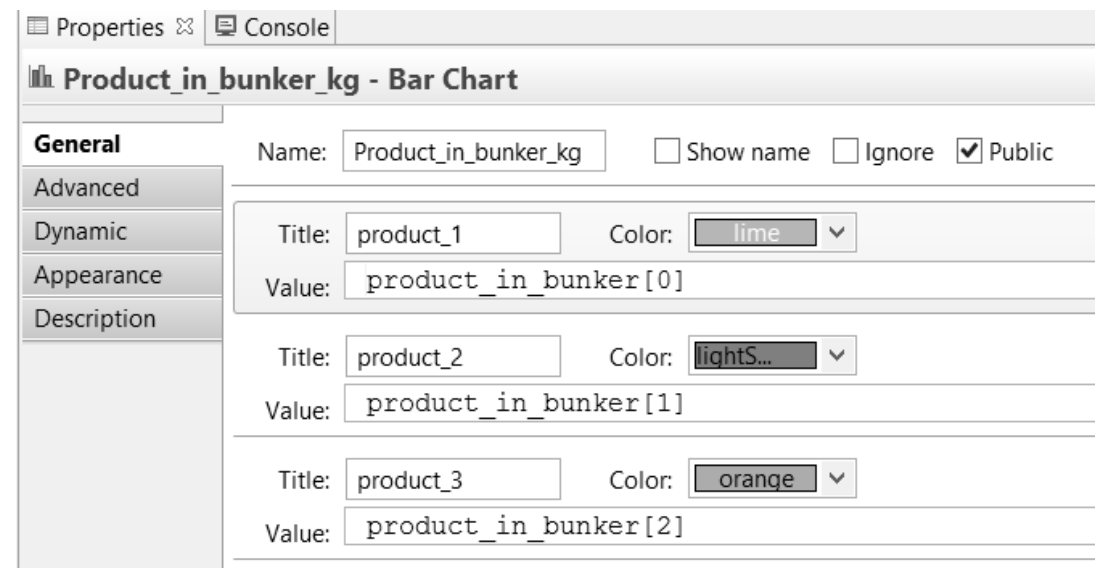

Fig. 3. The box of chart configuration for filling the hopper in AnyLogic 
Figure 3 shows that each element is bound to a value in the array. The value of the array elements varies in the logical production circuit in delay5 element in the field on enter, which is responsible for modelling of changes in the model state, when any element of the product arrives at the hopper.

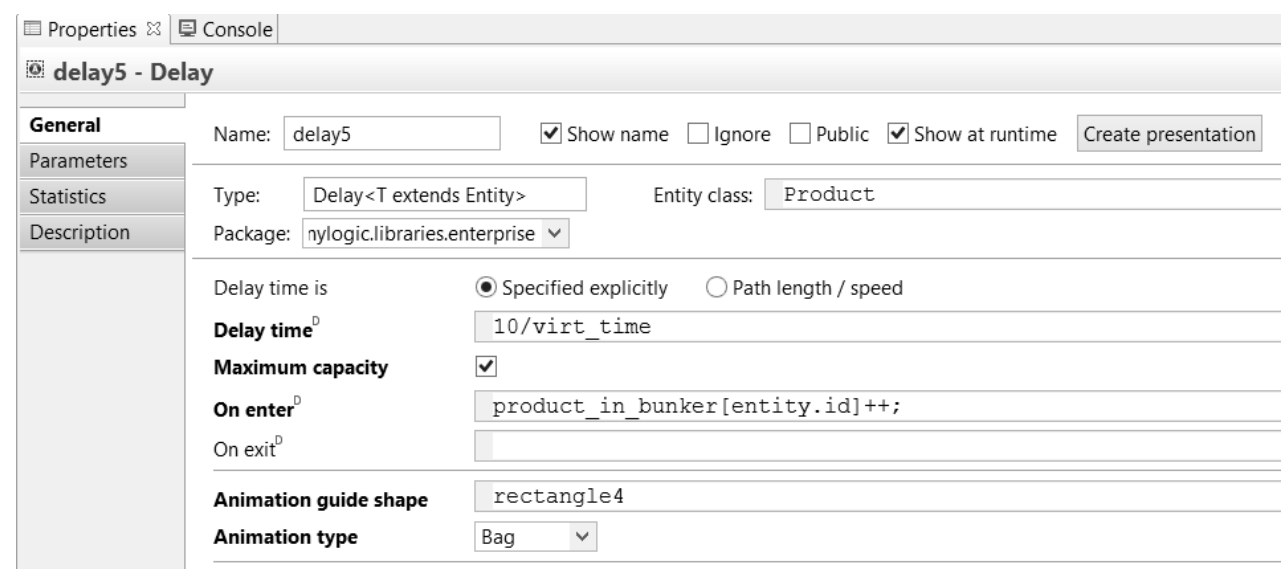

Fig. 4. Delay5 element

\subsection{Design of the event part of the model}

The main part of the model is logic circuits. For each element, its own logical circuit is developed. In our case there are 6 of them:

- logical circuit of production;

- logical circuit of breakdowns;

- logical circuit for workers of the production site;

- logical circuit of packaging;

- driver's logic circuit;

- logical circuit for trucks.

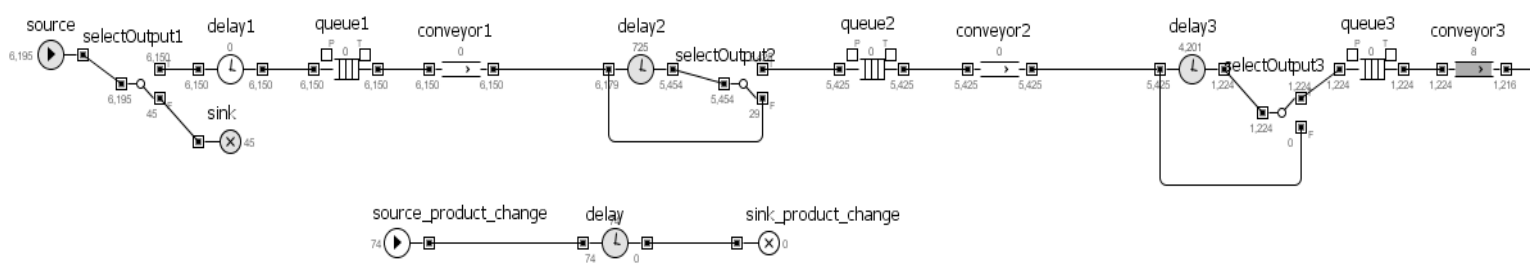

Fig. 5. Logical circuit of production at the beginning of the production site

Each conveyor has a selectOutput element before it, which checks if this conveyor can be used now. Selectoutput 2 is responsible for the second conveyor. It checks the value of the break_bool variable. If the value is true, then the product gets to the exit $\mathrm{T}$, that is, the conveyor. If the value is false, then the element enters the exit $\mathrm{F}$, and the failure request is generated: source_product_change.inject.

\subsection{Simulation of production sites of the enterprise}

Let us look at the logical circuit of the enterprise in Figure 6.

source - an element responsible for generating a logical unit of the product;

delay1 - press and pre-drying; 
delay2 - drying 1

delay3 - drying 2;

delay4 - refrigerator;

delay5 - hoppers;

delay6 - packing machine $3 \mathrm{~kg}$ (or $2 \mathrm{~kg}$ );

delay7 - packing machine $1 \mathrm{~kg}$ (or $0.9 \mathrm{~kg}$ );

batch, batch1 - pallet forming;

delay8, delay9 - transportation of products to the warehouse of finished products;

unbatch, unbatch1 - putting products into the warehouse of finished products;

queue10, delay10 - storage of products in the warehouse of finished products;

delay20 - loading of products to the truck;

sink1 - export of goods by truck from the enterprise.

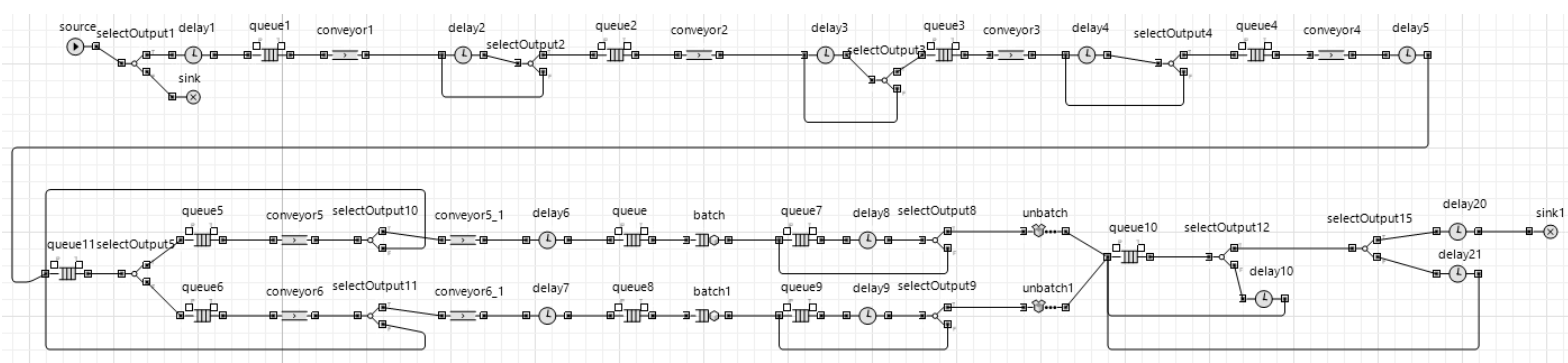

Fig. 6. Logical circuit of the enterprise

The logic of the design and operation of this circuit is similar to the logic of description in the development of the logic circuit, with the only difference that these elements perform their function in the logical circuit of the enterprise.

\subsection{Imitation of warehouse work}

Let us look at Figure 7.

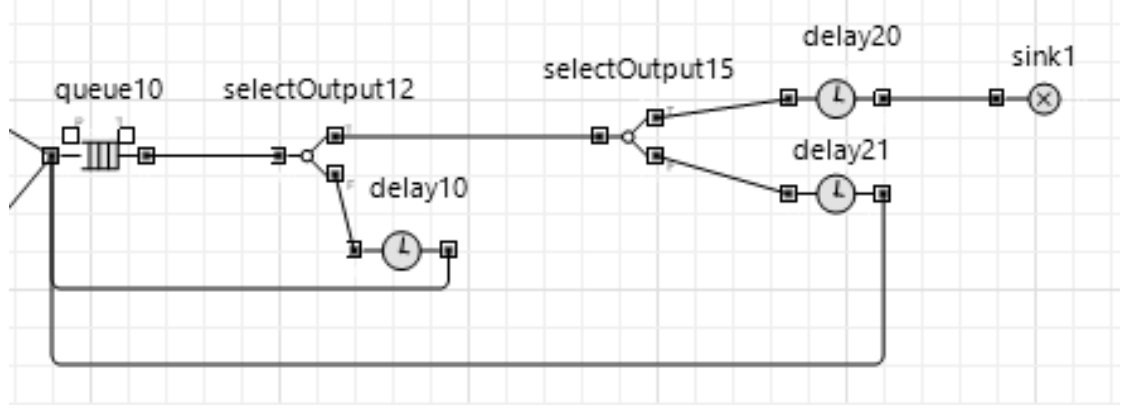

Fig. 7. Logical schema of the warehouse operation

As already noted, the storage of products in the warehouse is modeled by the elements queue10 and delay10. The selectOutput12 element verifies whether the machine is loadable, the selectOutput15 element checks if you still need to load the truck, or it has already been filled in. An element sink1 models the export of products from the warehouse.

In order for this circuit to work, you need to design the logical scheme of the forklift truck. This schema will change the state of the elements selectOutput12 and selectOutput 15 . Consider it in Figure 8. 


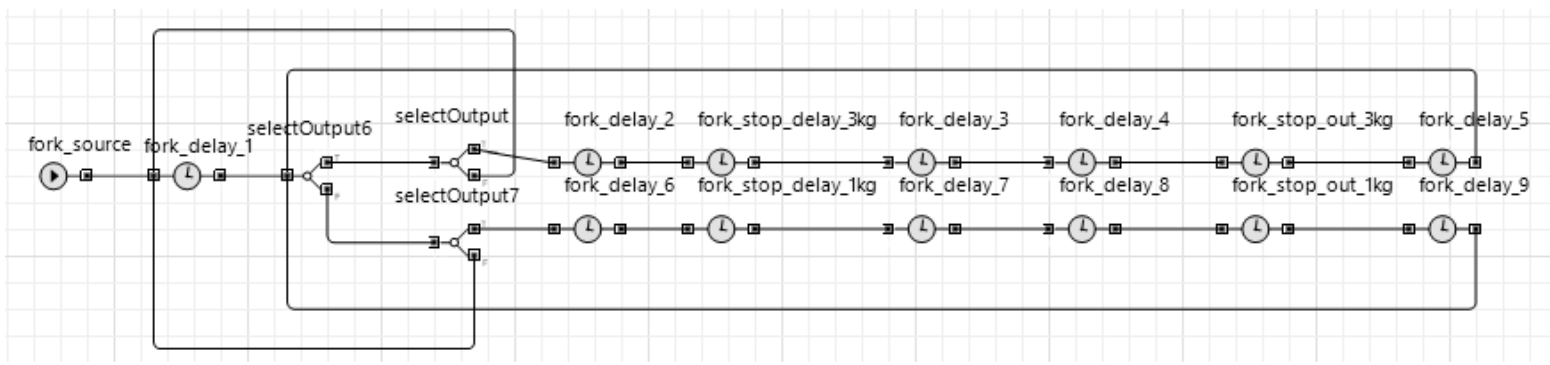

Fig. 8. The logical schema of the forklift truck movement

Fork_source - the element that generates a copy of the truck.

selectOutput6 - splits an instance into a possible type of truck.

selectOutput, selectoutput7 - decides whether it is possible now to come to the product.

fork-stop_out_3kg, fork_stop_out_1 kg - generates loading of the truck.

\subsection{Calculation of the production line coefficient of readiness}

The coefficient of readiness is the probability that an object will be able to work at any time, except for the scheduled periods during which the use of the object for its intended purpose is not provided.

The coefficient of readiness is a coefficient defined as the ratio of the time of successful work to the sum of time of the successful work and the forced idle time of the object taken during the same calendar period [14].

$$
\mathrm{K}_{\mathrm{r}}=\mathrm{t}_{\mathrm{w}} / \mathrm{t}_{\mathrm{w}}+\mathrm{t}_{\mathrm{p}}
$$

where $t_{w}-$ is total time of the proper operation of the object; $t_{p}-$ is total time of forced idle time.

To switch to a probabilistic interpretation, the values $t_{w}$ and $t_{p}$ are changed by the mathematical expectation of the time between adjacent failures and the recovery time, respectively.

$$
\mathrm{K}_{\mathrm{r}}=\mathrm{t}_{\mathrm{ar}} / \mathrm{t}_{\mathrm{ar}}+\mathrm{t}_{\mathrm{r}}
$$

where: $t_{\mathrm{ar}}-$ is average work before the refusal;

$t_{r}-$ is average recovery time.

Experimentally, we have got the following data:

Running before failure: $\mathrm{t}_{1}=47 \mathrm{~min}, \mathrm{t}_{2}=18 \mathrm{~min}, \mathrm{t}_{3}=360 \mathrm{~min}, \mathrm{t}_{4}=220 \mathrm{~min}, \mathrm{t}_{5}=34 \mathrm{~min}$.

Recovery time: $\mathrm{t}_{1 \mathrm{r}}=15 \mathrm{~min}, \mathrm{t}_{2 \mathrm{r}}=5 \mathrm{~min}, \mathrm{t}_{3 \mathrm{r}}=12 \mathrm{~min}, \mathrm{t}_{4 \mathrm{r}}=25 \mathrm{~min}, \mathrm{t}_{5 \mathrm{r}}=5 \mathrm{~min}$

Then

$$
\begin{gathered}
\mathrm{t}_{\mathrm{ar}}=(47+18+360+220+34) / 5=135,8 \mathrm{~min} . \\
\mathrm{t}_{\mathrm{r}}=(15+5+12+25+5) / 5=12,4 \mathrm{~min} .
\end{gathered}
$$

Thus, the coefficient of readiness is:

$$
K_{r}=135,8 / 135,8+12,4=0,916
$$




\section{CONCLUSION AND PROSPECTS FOR FURTHER RESEARCH}

The presented simulation model has been developed for the university course "CAD of packaging production" and can be implemented in the educational process for engineering students to study the stages of simulation of flexible production systems with the help of AnyLogic software. To accomplish the task, students work in teams, use modern software and integrate their theoretical knowledge with practical skills. Moreover, simulation models are created using real data from enterprises, which allows students to work with reliable information, entering actual parameters.

The use of simulation modelling both helps to avoid serious mistakes that arise in the creation of automated systems, and opens new horizons for research, in particular, the development of intelligent production systems.

Simulation modelling allows students to acquire skills in using modern software products. These skills will help students to practice real problem solving in their field.

As a result of studying the discipline "CAD of packaging production" and using AnyLogic software, students develop holistic understanding of automated processes and acquire the skills of modeling, analysis and optimization of the technological line.

\section{REFERENCES (TRANSLATED AND TRANSLITERATED)}

[1] A. Borshchev, "The Big Book of Simulation Modeling: Multimethod Modeling withAnyLogic" 6, 2013 (in English).

[2] C.M. Macali, M.J. North, "Tutorial on Agent-Based Modelling and Simulation", The University of Chicago, 2010. (in English).

[3] Gizem Gunes, Ali Fuat Guneri, "Agent-based simulationand an example in Anylogic”. Yıldız Technical University, Industrial Engineering Department, Istanbul, 2014 (in English).

[4] Björn F. Postema, Boudewijn R. Haverkort, "An AnyLogic simulation model for power and performance analysis of data centres", Proceedings of the 12th European Workshop on Computer Performance Engineering, EPEW 2015. Lecture Notes in Computer Science, vol. 9272, Springer, Switzerland, pp. 258272. doi:10.1007/978-3-319-23267-6_17 (in English).

[5] O.V. Karsayev, B.M. Morozov, R.A. Sabitov, G.S Smirnov, "Imitation modeling of the relay delivery system”, Bulletin of the Scientific Center for Life Safety, No. 1 (27), p. 45-56, 2016 (in Russian).

[6] I. N. Khaymovich, D.G. Skripachev, S. Yu. Kolesnikova, "Simulation of Production Cycle of Wire Production", Vestnik Samara State Aerospace University, T.14, No. 4, p. 151-154, 2015 (in Russian).

[7] E.V. Karmanova, Yu. EfimovaI, E.N.Guseva, N.N.Kostina, L.A.Saveleva, I.I.Bobrova, "Modeling of students' competency development in the higher education distant learning system", Proceedings of the 2016 Conference on Information Technologies in Science, Management, Social Sphere and Medicine (ITSMSSM 2016), p. 308-315, 2016 (in English).

[8] O. I. Morozova, I. A. Sipchenko, "Analysis of modern information systems and modeling tools used in industrial logistics", Aviation-space technology and technology, N. 6 (113), pp. 108-112, 2014, ISSN $1727-7337$ (in Russian).

[9] Yu.G. Karpov, "Imitation modeling of systems. An Introduction to Modeling with AnyLogic 5", BHVPetersburg, 390 p., 2005. (in Russian).

[10] B.A. Palchevskyi, O.A. Krestyanpol, B.P. Valetsky, D.V. Bondarchuk, V.S. Rak. "Fundamentals of CAD of packing equipment", Training Manual, Lutsk, 160 p., 2008 (in Ukrainian).

[11] B.A. Palchevskyi, L.Yu. Krestyanpol, "Imitation model of optimization of packaging system of alcohol products", Polygraphy and publishing, №3-4 (63-64) p.37-43, 2013. (in Ukrainian).

[12] B.A. Palchevskyi, O.A. Krestyanpol, L.Yu. Krestyanpol, "Information technologies in designing the system of protection of packed products", monograph, Lutsk, 160 p., 2015. (in Ukrainian).

[13] B.A. Palchevskyi, T.L. Varanitsky, "Information provision of optimization synthesis of the structure of flexible production package modules", Technological complexes, No. 1, c. 201-205, 2014. (in Ukrainian).

[14] B. Palchevskyi, A. Świć, H. Krestyanpol, "Increasing efficiency of flexible manufacturing systems based on computer product grouping", Advances in Science and Technology Research Journal, vol. 12, Issue 2, p. 6-10. doi: 10.12913/22998624/920932018. (in English). 


\title{
ВИКОРИСТАННЯ СИСТЕМИ АNYLOGIC ДЛЯ МОДЕЛЮВАННЯ ГНУЧКОЇ АВТОМАТИЗОВАНОЇ СИСТЕМИ ПАКУВАННЯ ПІД ЧАС НАВЧАННЯ СТУДЕНТІВ-ІНЖЕНЕРІВ
}

\author{
Пальчевський Богдан Олексійович \\ доктор технічних наук, професор \\ Луцький національний технічний університет, м. Луцьк, Україна \\ ORCID ID 0000-0002-4000-4992 \\ pac@tf.dtu.lutsk.ua
}

\author{
Крестьянполь Олена Анатоліївна \\ кандидат технічних наук, доцент \\ Луцький національний технічний університет, м. Луцьк, Україна \\ ORCID ID 0000-0002-6631-0226 \\ helenakrist61@gmail.com \\ Крестьянполь Любов Юріївна \\ кандидат технічних наук, доцент \\ Луцький національний технічний університет, м. Луцьк, Україна \\ ORCID ID 0000-0003-3617-7900 \\ Krist_88@i.ua
}

\begin{abstract}
Анотація. У статті авторами розглянуто можливості організації навчальної роботи студентів інженерної спеціальності “131. Прикладна механіка” у вивченні дисципліни “САПР пакувального виробництва" 3 використанням спеціалізованого програмного забезпечення компанії The AnyLogic Company.

У роботі представлено програмні продукти для автоматизованого розрахунку та моделювання технологічного процесу пакування. Під час навчання студент оволодіє методиками автоматизованого розрахунку та проєктування елементів та вузлів пакувального обладнання, особливостями їх реалізації з використанням сучасних CAD та САМ систем.

Метою моделювання технологічних процесів пакування $є$ підвищення їх продуктивності за рахунок визначення та обгрунтування оптимальних параметрів. Дослідження технологічних процесів на основі імітаційного моделювання дозволяє студенту визначити взаємозв'язки, виділити техніко-економічні показники, оцінити вплив на прибутковість, визначити напрямки розвитку та шляхи вдосконалення техніко-технологічної бази.

У роботі представлено методику розробки імітаційної моделі гнучкої автоматизованої лінії на прикладі виробництва макаронних виробів. Авторами виділено етапи моделювання роботи гнучкої автоматизованої системи пакування. Визначено критерії, які впливають на технологічний процес пакування сипкої продукції. Вибрано параметри для побудови імітаційної моделі. Для більш детального розуміння процесу та адекватної побудови моделі здійснено формалізований опис пакувальної лінії. За допомогою програмного забезпечення компанії The AnyLogic Company студенти розробляють подієву частину моделі, імітацію роботи цехів підприємства, імітацію роботи складу підприємства.

У результаті в розробленій імітаційній моделі проведено дослідження стану завантаженості елементів виробництва, визначено проблемні структурні елементи та розраховано коефіцієнт готовності технологічної лінії. Віртуальна модель технологічної лінії дала змогу перевірити майбутню технологічну лінію на адекватність, технологічність та безвідмовність.

У результаті вивчення дисципліни “САПР пакувального виробництва" та програмного продукту AnyLogic у студентів формуються цілісні уявлення про автоматизований технологічний процес та набуваються навики моделювання, аналізу та оптимізації технологічної лінії.
\end{abstract}

Ключові слова: імітаційне моделювання; гнучка автоматизована система; модель; формалізований опис; коефіцієнт готовності; дискретно-подієва абстракція; логічна схема. 


\title{
ИСПОЛЬЗОВАНИЕ СИСТЕМЫ АNYLOGIC ДЛЯ МОДЕЛИРОВАНИЯ ГИБКИХ АВТОМАТИЗИРОВАННЫХ СИСТЕМ УПАКОВКИ ВО ВРЕМЯ ОБУЧЕНИЯ СТУДЕНТОВ-ИНЖЕНЕРОВ
}

\author{
Пальчевский Богдан Алексеевич \\ доктор технических наук, профессор \\ Луцкий национальный технический университет, г. Луцк, Украина \\ ORCID ID 0000-0002-4000-4992 \\ pac@tf.dtu.lutsk.ua
}

\author{
Крестьянполь Елена Анатольевна \\ кандидат технических наук, доцент \\ Луцкий национальный технический университет, г. Луцк, Украина \\ ORCID ID 0000-0002-6631-0226 \\ helenakrist61@gmail.com
}

Крестьянполь Любовь Юрьевна

кандидат технических наук, доцент

Луцкий национальный технический университет, г. Луцк, Украина

ORCID ID 0000-0003-3617-7900

Krist_88@i.ua

\begin{abstract}
Аннотация. В статье авторами рассмотрены возможности организации учебной работы студентов инженерной специальности 131. "Прикладная механика” в изучении дисциплины “САПР упаковочного производства" с использованием специализированного программного обеспечения компании The AnyLogic Company.

В работе представлены программные продукты для автоматизированного расчета и моделирования технологического процесса упаковки. Во время изучения студент овладеет методиками автоматизированного расчета и проектирования элементов и узлов упаковки и особенностями их реализации с использованием современных CAD и CAM систем.

Целью моделирования технологических процессов упаковки является повышение их производительности за счет определения и обоснования оптимальных параметров. Исследование технологических процессов на основе имитационного моделирования позволяет студенту определить взаимосвязи, выделить технико-экономические показатели, оценить влияние на прибыльность, определить направления развития и пути совершенствования технико-технологической базы.

В работе представлена методика разработки имитационной модели гибкой автоматизированной линии на примере производства макаронных изделий. Авторами выделены этапы моделирования работы гибкой автоматизированной системы упаковки. Определены критерии, которые влияют на технологический процесс упаковки сыпучей продукции. Выбрано параметры для построения имитационной модели. Для более детального понимания процесса и адекватного построения модели осуществлено формализованное описание упаковочной линии. С помощью программного обеспечения компании The AnyLogic Company студенты разрабатывают событийную часть модели, имитацию работы цехов предприятия, имитацию работы склада предприятия.

В результате в разработанной имитационной модели проведено исследование состояния загруженности элементов производства, определены проблемные структурные элементы и рассчитан коэффициент готовности технологической линии. Виртуальная модель технологической линии позволила проверить будущую технологическую линию на адекватность, технологичность и безотказность.

Во время изучения дисциплины “САПР упаковочного производства" и программного продукта AnyLogic у студентов формируются целостное представление об автоматизированном технологическом процессе и приобретаются навыки моделирования, анализа и оптимизации технологической линии.
\end{abstract}

Ключевые слова: имитационное моделирование; гибкая автоматизированная система; модель; формализованное описание; коэффициент готовности; дискретно-событийная абстракция; логическая схема. 